\title{
FAKTOR-FAKTOR YANG MENGHAMBAT KINERJA PELAYANAN PUBLIK DI DINAS KEPENDUDUKAN DAN PENCATATAN SIPIL KOTA BATAM
}

\author{
Riko Riyanda \\ Universitas Putera Batam, Batam, Kepulauan Riau \\ Email : riyanda.fisip@gmail.com
}

\begin{abstract}
Abstrak
Reformasi akan dapat memenuhi tuntutan masyarakat terutama berkaitan dengan perbaikan kualitas layanan publik, namun harapan itu dianggap masih jauh dari kenyataan. Termasuk pelayanan yang di berikan oleh Dinas Kependudukan dan Catatan Sipil Kota Batam masih belumlah optimal. Hal ini ditandai dengan masih banyak keluhan dari masyarakat yang merasa tidak puas dengan pelayanan yang di berikan oleh Dinas Kependudukan dan Catatan Sipil Kota Batam. Tujuan dalam penerlitian ini adalah untuk mengetahui faktor penghambat dan penumjang proses pelayanan publik yang dilayani oleh Dinas Kependudukan dan Catatan Sipil Kota Batam. Pendekatan yang digunakan dalam penelitian ini adalah pendekatan kualitatif. Tipe penelitian yang digunakan adalah deskriptif.Metode pengambilan data dilakukan dengan cara observasi dan dokumentasi, teknik pemilihan informan dilkukan dengan purposive sampling, teknik analisis data dilakukan dengan reduksi data, penyajian data dan penarikan kesimpulan.

Dari hasil penelitian ditemukan bahwa peneliti menemukan kendala pelayanan di Disdukcapil Kota batam dari segi tangible, asurance dan reability masih belum optimal. Penyebabnya adalah sumber daya manusia dan faktor sarana dan prasarana serta sistem yang tidak tranparansi.Sedangkan faktor pendukung data base online terintegrasi secara nasional sangat membantu agar tidak terjadi data ganda dokumen kependudukan.
\end{abstract}

Kata Kunci : Pelayanan Publik, Dimensi Kepuasan Pelayanan

\section{Abstract}

Reforms will be able to meet the demands of the public, especially related to the improvement of the quality of public services, but it is still far from reality. Including services are provided by the Department of Population and Civil Registration Batam still not yet optimal. It is characterized by the many complaints from people who are not satisfied with the service that is given by the Department of Population and Civil Registration Batam.The approach used in this study is a qualitative approach. Type of research is descriptive.Methods of data collection is done by observation and documentation, informant selection technique is done by purposive sampling, data analysis performed by data reduction, data presentation and conclusion.

The research found that investigators found the constraints of service in terms of Batam City Disdukcapil tangible, asurance and reability still not optimal. The cause is a factor of human resources and infrastructure, and systems that are not transparency. While the factors supporting online data base nationally integrated very helpful in order to avoid double data residence documents.

Keywords: Public Service, Dimension Satisfaction Services

\section{PENDAHULUAN}

Kepemerintahan yang baik (good governance) merupakan isu sentral yang paling mengemuka dalam administrasi publik dewasa ini. Tuntutan gencar yang dilakukan oleh masyarakat kepada pemerintah untuk melaksanakan penyelenggaraan pemerintahan yang baik adalah sejalan dengan meningkatnya tingkat pengetahuan dan pendidikan masyarakat, selain adanya pengaruh globalisasi. (Sedarmayanti, 2012:4).Hal ini seiring dengan tujuan utama penyelenggaraan otonomi daerah, yaitu 
untuk meningkatkan pelayanan publik (publik service) dan memajukan perekonomian daerah. (Utang Rosidin, 2015:420).

Diberlakukannya Peraturan Pemerintah Nomor 41 Tahun 2007 tentang Organisasi Perangkat Daerah dan Permendagri Nomor 57 Tahun 2007 tentang Petunjuk Teknis Penataan Organisasi Perangkat Daerah, maka pemerintah daerah di masing-masing wilayah membentuk berbagai macam organisasi perangkat daerah untuk melaksanakan otonomi dalam rangka kemajuan dan kesejahteraan rakyat, dunia usaha dan daerah itu sendiri. Implementasi peraturan pemerintah tersebut akan banyak berpengaruh terhadap format kelembagaan pemerintah di daerah serta sangat menentukan nasib pemerintah daerah dan nasib rakyat daerah, sebab apabila pemerintah daerah akan benar-benar mewujudkan kehendak memberdayakan rakyat maka dalam mengimplementasikan peraturan pemerintah tersebut, pemerintah daerah harus eksis dengan performa yang efisien dan efektif (miskin struktur kaya fungsi).

Sebagai tindak lanjut dari adanya kebijakan tersebut, Pemerintah Kota Batam mengeluarkan Peraturan Daerah Nomor 12 Tahun 2007 tentang pembentukan Struktur Organisasi dan Tata Kerja Dinas Daerah Kota Batam. Salah satu dinas yang dibentuk tersebut diantaranya adalah Dinas Kependudukan dan Pencatatan Sipil yang susunan organisasi dan tata kerjanya diatur oleh Peraturan Walikota Batam Nomor 26 Tahun 2010 tentang uraian tugas pokok dan fungsi dinas daerah Kota Batam, bahwa Dinas Kependudukan dan Pencatatan Sipil Kota Batam mempunyai tugas melaksanakan urusan pemerintahan daerah berdasarkan atas asas otonomi dan tugas pembantuan di bidang kependudukan dan pencatatan sipil serta tugas lain yang diberikan walikota sesuai dengan lingkup tugas dan fungsinya.

Kemudian dalam proses pelayanan yang prima Dinas Kependudukan dan Pencatatan Sipil diatur regulasi pelayanan dokumen kependudukan Undang-Undang Nomor 24 Tahun 2013 yang dilanjutkan lagi oleh Peraturan Daerah Nomor 1 Tentang pelaksanaan administasi kependudukan Kota Batam. Tugas pokok dan fungsi Dinas Kependudukan dan Pencatatan Sipil secara spesifik hanya mencakup 2 (dua) elemen utama, yaitu;

1) Formulasi kebijakan bidang kependudukan dan catatan sipil

2) Pelayanan bidang kependudukan dan catatan sipil

Disamping itu, sebagai salah satu unit pelaksana daerah (perangkat daerah), Dinas Kependudukan dan Pencatatan Sipil juga memiliki tugas dan kewajiban untuk menyelenggarakan tugas pemerintahan umum serta tugas lainnya yang diperintahkan oleh pimpinan di lingkungan Pemerintah Kota Batam.Dilain pihak, dalam rangka mengimbangi perkembangan isu tentang pelayanan publik yang semakin mengemuka, maka perlu dilakukan upaya peningkatan kinerja layanan maupun kualitas SDM, terutama yang bertanggungjawab atas terselenggaranya pelayanan prima bagi masyarakat umum.

Dinas kependudukan sebagai leadingsektor yang menangani terkait dengan pendaftaran penduduk dan pencatatan sipil yang memberikan layanan agar tercipta tertib administrasi kependudukan bagi setiap warga negara yang telah cukup umur dan mengalami peristiwa penting, wajib melengkapi diri dengan identitas kependudukannya.

Kendati demikian pelayanan yang di berikan oleh Dinas Kependudukan dan Pencatatan Sipil Kota Batam masih belumlah maksimal, dengan masih banyak keluhan dari masyarakat yang merasa tidak puas dengan pelayanan yang diberikan oleh Dinas Kependudukan dan Pencatatan Sipil Kota Batam. Presentasi yang tertinggi keluhan yang disampaikan oleh masyarakat terkait dengan pelayanan administrasi kependudukan adalah menyangkut masalah pembuatan KTP dan KK sebagaimana yang tertuang dalam tabel dibawah ini: 
Tabel 1.1

Kasus-Kasus Pelayanan Publik di Kota Batam Tahun 2014

\begin{tabular}{|c|c|c|l|l|}
\hline NO & $\begin{array}{l}\text { JENIS-JENIS } \\
\text { PELAYANAN }\end{array}$ & $\begin{array}{l}\text { JUMLAH } \\
\text { KASUS }\end{array}$ & $\begin{array}{l}\text { SATUAN KERJA } \\
\text { PENYEDIA } \\
\text { LAYANAN }\end{array}$ & $\begin{array}{l}\text { Persentase } \\
\text { Ketidakpuasan } \\
\text { Masyarakat } \\
\text { (Berdasarkan } \\
\text { survey) }\end{array}$ \\
\hline 1 & Kesehatan & 15 & Dinas Kesehatan RSUD & 11,5 \\
\hline 2 & Pendidikan & 10 & Dinas Pendidikan & 7,7 \\
\hline 3 & KK & $\mathbf{6 0}$ & $\begin{array}{l}\text { Dinas Kependudukan } \\
\text { dan Pencatatan sipil }\end{array}$ & $\mathbf{5 8 , 6}$ \\
\hline 4 & KTP & 75 & $\begin{array}{c}\text { Dinas Kependudukan } \\
\text { dan catatan sipil }\end{array}$ & 76,65 \\
\hline 5 & Tenaga Kerja & 23 & Dinas Tenaga kerja & 17,6 \\
\hline 6 & Sampah & 40 & $\begin{array}{c}\text { Dinas kebersihan dan } \\
\text { pertamanan }\end{array}$ & 30,8 \\
\hline
\end{tabular}

Sumber : Inspektorat Daerah Kota Batam 2014

Dari tabel tersebut di atas, dapat diketahui bahwa kasus pelayanan publik yang menduduki tempat teratas di Kota Batam adalah pelayanan KTP dan Kartu keluarga(KK). Kemudian berdasarkan hasil survei terhadap masyarakat yang menggunakan layanan publik yang dikeluarkan oleh Inspektorat Daerah Kota Batam terdapat fakta bahwa pelayanan KTP menempati persentase tertinggidalam hal ketidakpuasan masyarakat.Hal ini menunjukkan buruknya kinerja birokrasi dalam melaksanakan pelayanan umum bagi masyarakat.

Kondisi ini memberikan indikasi bahwa harapan reformasi akan dapat memenuhi tuntutan masyarakat terutama berkaitan dengan perbaikan kualitas layanan publik dari birokrasi masih jauh dari kenyataan. Sesuatu yang penting kemudian adalah bagaimana pemerintah dapat menjalankan fungsifungsi tersebut agar dapat menghasilkan barang dan jasa (pelayanan) yang ekonomis, efektif, efisien dan akuntabel kepada seluruh masyarakat yang membutuhkannya.

Dengan demikian maka, dapat dipahami keterkaitan antara kinerja birokrasi dengan proses layanan publik menjadi sangat penting melalui analisis dan penilaian tentang kinerja, sebab dalam berlangsungnya proses tersebut, telah melibatkan interaksi antara pemerintah dan masyarakat. Selain itu penilaian terhadap kinerja merupakan suatu kegiatan yang sangat penting karena dapat digunakan sebagai ukuran keberhasilan suatu organisasi pelayanan publik dalam mencapai misinya.

Berangkat dari uraian diatas, maka untuk mewujudkan pelaksanaan pelayanan umum secara prima sebagai wujud dari penyelenggaraan pemerintahan di daerah yang serasi dan terpadu dalam rangka pencapaian tujuan akhir yang maksimal dan efisien, diperlukan ada upaya kajian dan analisis terkait dengan kinerja pelayanan publik pada Kantor Dinas Kependudukan dan Pencatatan Sipil Kota Batam beserta berbagai faktor yang mempengaruhi berdasarkan asumsi teori yang dibangun dalam kerangka konseptual, sehingga kinerja organisasi pemerintahan khususnya pada Kantor Dinas Kependudukan dan Pencatatan Sipil Kota Batam, diharapkan akan dapat memenuhi harapan dan memuaskan pengguna jasa melalui perbaikan kinerja layanan publik yang dilakukan secara terarah dan sistematis.

Tulisan ini bertujuan untuk mengetahui proses pelayanan publik yang dilayani oleh Dinas Kependudukan dan Pencatatan Sipil Kota Batam dan untuk menganalisis faktor-faktor yang mendukung dan menghambat kinerja pelayanan publik di Dinas Kependudukan dan Pencatatan Sipil Kota Batam. Proses pelayanan publik dalam institusi pemerintah bukan menjadi rahasia umum lagi dalam fenomena 
administrasi publik. Oleh karena itu untuk melihat fenomena ini secara utuh, maka tulisan ini untuk menjawab persoalan dari fenomena yang kurang memuaskan dari proses pelayanan publik di Kota Batam. 1. Pelayanan Publik

Undang-Undang No. 25 Tahun 2009 tentang Pelayanan Publik mendefinisikan pelayanan publik sebagai berikut: Pelayanan publik adalah kegiatan atau rangkaian kegiatan dalam rangka pemenuhan kebutuhan pelayanan sesuai dengan peraturan perundang-undangan bagi setiap warga negara dan penduduk atas barang, jasa, dan/atau pelayanan administratif yang disediakan oleh penyelenggara pelayanan publik.Keputusan Menteri Pendayagunaan Aparatur Negara Nomor: Kep/25/M.Pan/2/2004 Tentang Pedoman Umum Penyusunan Indeks Kepuasan Masyarakat Unit Pelayanan Instansi Pemerintah menjelaskan Pelayanan publik adalah segala kegiatan pelayanan yang dilaksanakan oleh penyelenggara pelayanan publik sebagai upaya pemenuhan kebutuhan penerima pelayanan, maupun dalam rangka pelaksanaan ketentuan peraturan perundang-undangan.

Agus Dwiyanto (2010: 2) menyatakan bahwa pelayanan publik sebenarnya memiliki kisaran yang sangat luas, yaitu mencakup pelayanan untuk memenuhi kebutuhan barang publik, hak dasar, kewajiban pemerintah, dan komitmen nasional.Menurut Kotler dalam Sampara Lukman yang dikutip oleh Sinambela (2010: 4): "Pelayanan adalah setiap kegiatan yang menguntungkan dalam suatu kumpulan dan menawarkan kepuasan meskipun hasilnya tidak terikat pada suatu produk secara fisik".

Selanjutnya Sampara yang dikutip oleh Sinambela (2010: 5): "Pelayanan adalah suatu urutan kegiatan yang terjadi dalam interaksi langsung antarseseorang dengan orang lain atau mesin, dan meyediakan kepuasan pelanggan."Menurut Kurniawan (dalam Sinambela, 2010: 5) pelayanan publik diartikan sebagai pemberi pelayanan (melayani) keperluan orang atau masyarakat yang mempunyai kepentingan pada organisasi itu sesuai dengan aturan pokok dan tata cara yang ditetapkan.

Dengan demikian, pelayanan publik yang profesional, dicirikan oleh adanya akuntabilitas dan responsibilitas dari pemberi layanan (aparatur pemerintah) yang efektif dalam pencapaian tujuan dan sasaran. Bila jasa layanan yang diterima (perceived service) sesuai dengan yang diharapkan, maka kualitas jasa layanan yang dipersepsikan baik dan memuaskan. Jika jasa yang diterima melampaui harapan pelanggan, maka kualitas jasa dipersepsikan sebagai kualitas yang ideal. Sebaliknya bila jasa layanan yang diterima lebih rendah dari pada diharapkan, maka kualitas layanan akan dipersepsikan buruk.Baik atau buruknya kualitas jasa layanan tergantung kepada kemampuan penyedia jasa dalam memenuhi harapan pelanggan secara konsisten dan berakhir pada persepsi pelanggan.Ini berarti bahwa citra kualitas yang baik bukanlah berdasarkan sudut pandang penyelenggara, tetapi harus dilihat dari sudut pandang atau persepsi pelanggan.

2.Dimensi Kualitas Pelayanan Publik Ada beberapa beberapa dimensi kualitas pelayanan menurut (Zeithmal, Berry dan Parasuraman), yaitu:

1. Dimensi Berwujud (Tangibel)

Dimensi berwujud (Tanggibel), didefisnikan sebabagai penampilan kualitas peralatan dan petugas memberikan pelayanan jasa karena suatu service jasa tidak dapat dilihat, dicium, diraba dan didengar. Dengan demikian bukti yang wujud merupakan satu indikator yang paling kongkrit. Wujudnya berupa fasilitas yang secara nyata dapat terlihat.

2. Dimensi Keandalan (Reability)

Dimensi keandalan (Reability) adalah kemampuan memberikan pelayanan yang dijanjikan dengan segera dan memuaskan. Menurut Lovelock, keandalan adalah kemampuan perusahaan untuk menampilkan pelayanan yang dijanjikan secara tepat dan konsisten. Keandalan tepat diartikan mengerjakan dengan benar sampai kurun waktu tertentu. Pemenuhan janji pelayanan yang tepat dan memuaskan meliputi ketepatan waktu dan kecakapan dalam menanggapi keluhan pelanggan serta pemberi pelayanan.

3. Dimensi daya tanggap (Responsiveness) 
Dimensi daya tanggap (responsiveness) adalah suatu kemauan untuk membantu dan memberikan pelayanan yang cepatdan tepat kepada pelanggan, dengan penyampaian informasi yang jelas. Daya tanggap: sikap tanggap pegawai dalam memberikan pelayanan yang dibutuhkan dan dapat menyelesaikan dengan cepat. Kecepatan pelayanan yang diberikan merupakan sikap tanggap dari petugas dalam pemberian pelayanan yang dibutuhkan. Dimensi daya tanggap merupakan dimensi yang bersifat paling dinamis. Hal ini dipengaruhi oleh faktor perkembangan teknologi. Salah satu contoh aspek daya tanggap dalam pelayanan adalah kecepatan.

4. Dimensi Kepastian (assurance)

Dimensi kepastian (assurance) adalah dimensi kualitas pelayanan yang berhubungan dengan kemampuan dalam menanamkan kepercayaan dan keyakinan kepada konsumen. Dimensi kepastian meliputi kemampuan tenaga kerja atas pengetahuan terhadap produk meliputi kemampuan karyawan atas pengetahuan terhadap produk secara tepat, kualitas keramah tamahan, perhatian dan kesopanan dalam memberikan pelayanan, keterampilan dalam memberikan keamanan di dalam memanfaatkan jasa yang ditawarkan dan kemampuan di dalam menanamkan kepercayaan konsumen terhadap jasa yang ditawarkan.

\section{Dimensi Empati (Empathi)}

Dimensi empati adalah kesediaan untuk peduli dan memberikan perhatian pribadi kepada pengguna jasa. Pelayanan yang empatik sangat memerlukan sentuhan/perasaan pribadi. Dimensi empati adalah dimensi yang memberikan peluang besar untuk menciptakan pelayanan surprise: yaitu sesuatu yang tidak diharapkan pengguna jasa, tetapi ternyata diberikan oleh penyedia jasa.

3. Asas Pelayananan

Beberapa asas dalam penyelenggraan pelayanan pemerintah yang harus diperhatikan adalah sebagai berikut:

a. Empati dengan constumers. Pegawai yang melayani urussan pelayanan dan instansi penyelenggaraan jasa harus dapat berempati dengan masyarakat pengguna jasa

b. Pembatasan prosedur. Prosedur harus dirancang sependek mungkin

c. Kejelasan tata cara pelayanan. Tata cara pelayanan harus didesain sesederhana mungkin dan dikombinasikan kepada masyarakat pengguna jasa pelayanan

d. Minimalisasi persyaratan pelayanan. Persyaratan dalam mengurus pelayanan harus dibatasi sedikit mungkin dan sebanyak yang benar-benar diperlukan

e. Kejelasan wewenang. Kewenangan pegawai yang melayani masyarakat pengguna jasa pelayanan harus dirumuskan sejelas mungkin dengan membuat bagan tugas dan ditribusi kewenangan

f. Tranparansi biaya. Biaya pelayanan harus ditetapkan seminimal mungkin dan setransparan mungkin

g. Kepastian jadwal dan durasi pelayanan

h.Minimalisasi formulir. Formulir-formulir dirancang secara efesien, sehingga akan menghasilkan formulir komposit (satu formulir dapat dipakai untuk berbagai keperluan)

i. Maksimalisasi masa berlakunya

j. Kejelasan hak dan kewajiban

\section{METODE}

Penelitian ini menggunakan deskriptif kualitatif.Penelitian deskriptif kualitatif adalah salah satu metode untuk mendapatkan kebenaran dan tergolong sebagai penelitian ilmiah yang dibangun atas dasar teori-teori yang berkembang dari penelitian dan terkontrol atas dasar empirik.Dalam penelitian ini, peneliti berusaha memecahkan masalah dengan menggambarkan proses Kinerja Pelayanan Publik Pada Kantor Dinas Kependudukan Dan Catatan Sipil Kota Batam beserta berbagai faktor yang 
mempengaruhinya agar tercipta optimalisasi penyelenggaraan tugas Dinas Kependudukan Dan Catatan Sipil Kota Batam yang baik, berdaya guna dan berhasil guna. Karena tujuan tersebut, maka relevan jika penelitian ini dilakukan dengan menggunakan pendekatan kualitatif.

Data yang diperoleh dari penelitian ini akan dianalisis dengan menggunakan model analisis interaktif dari Miles dan Huberman. Miles \& Huberman (1994) mengungkapkan bahwa proses analisis data terdiri dari tiga kegiatan pokok yaitu:

1. Reduksi data (data reduction), adalah suatu bentuk analisis yang menajamkan, menggolongkan, mengarahkan, membuang yang tidak perlu dan mengorganisasikan dengan cara sedemikian rupa sehingga kesimpulan-kesimpulan finalnya dapat ditarik dan diverifikasi. Pada tahapan ini, peneliti berupaya memilih dan memilih data primer dan skunder penganggaran partisipatif di Kabupaten Bima yang telah diperoleh dilapangan sesuai dengan kebutuhan analisis data. Data-data yang tidak diperlukan akan disisihkan. Proses ini berlangsung terus menerus selama proses penelitian berjalan sampai penelitian berakhir.

2. Penyajian data (data display), merupakan bagian dari analisis untuk menampilkan data yang diperoleh melalui kegiatan reduksi sehingga memungkinkan peneliti menarik kesimpulan dan mengambil tindakan. Penyajian data dilakukan dalam penelitian dilakukan secara naratif dan dapat pula disajikan dalam bentuk tabel, diagram, matriks, bagan dan bentuk lainnya mengenai penganggaran partisipatif di Kabupaten Bima. Hal ini dilakukan sebagai dasar untuk menarik kesimpulan dan verifikasi.

3. Menarik kesimpulan dan verifikasi terhadap data yang terkumpul (conclution). Menarik kesimpulan pada hakikatnya adalah kegiatan yang dilakukan untuk mendapatkan keabsahan data (validitas) selama penelitian, sedangkan verifikasi adalah suatu tujuan ulang atau pembuktian terhadap kesimpulan yang telah diambil. Untuk mendapatkan data yang valid diperlukan verifikasi terhadap data yang ada sehingga kesimpulan yang dibuat dapat dipertanggungjawabkan. Peneliti mulai mengambil kesimpulan atau verifikasi sejak proses pengumpulan data dilakukan. Setiap data yang direduksi dan disajikan pada dasarnya telah memiliki kesimpulan sesuai dengan konteksnya, tetapi kesimpulan yang diambil masih bersifat parsial, diragukan dan belum sempurna. Kemudian dengan bertambahnya data, kesimpulan semakin teruji dan kuat.

\section{HASIL DAN PEMBAHASAN}

\section{Pelayanan Kependudukan Dan Pencatatan Sipil}

Pada dasarnya pemerintahan dibentuk untuk memberikan pelayanan kepada masyarakat. Pemerintah tidaklah diadakan untuk melayani dirinya sendiri, tetapi untuk melayani masyarakat serta menciptakan kondisi yang memungkinkan setiap anggota masyarakat mengembangkan kemampuan dan kreatifitasnya demi mencapai tujuan bersama. Oleh karenanya, birokrasi publik berkewajiban dan bertangung jawab untuk memberikan pelayanan publik yang baik dan profesional. Salah satu organ pemerintah yang berperan penting dalam menjalankan pelayanan adalah Dinas Kependudukan dan Pencatatan Sipil. Melihat kebutuhannya menunjukkan bahwa di Dinas Kependudukan dan Pencatatan Sipil masih kurangnya sarana dan fasilitas, kurangnya keahlian pertugas, masih terdapatnya suap/sogokan, kurangnya keahlian pegawai, kurangnya pemahaman masyarakat dalam pengurusan administrasi, kurang ramahnya petugas dalam masyarakat. Sehingga hal itu bisa menghambat proses pelayanan prima yang sesuai dengan harapan setiap orang yang membutuhkan pelayanan di Dinas Kependudukan dan Pencatatan Sipil tersebut.

Kendala yang ditemukan dalam pelayanan Dinas Kependudukan dan Pencatatan Sipil Kota Batam: Kendala Pelayanan Dinas Kependudukan dan Pencatatan Sipil Dari Aspek Tangibel (Terjamah) 
Berdasarkan hasil observasi di lapangan, dari segi tangibel (terjamah) adalah berupa penampilan fsik, sarana dan prasarana gedung. Secara operasional bukti fisik ini dijabarkan menjadi beberapa indikator dari aspek tangibel ini adalah lokasi, fasilitas, suasana tempat layanan, kemampuan sumber daya manusia, kecukupan jumlah petugas dan kejelasan informasi. Setelah peneliti melakukan penelitian di Dinas Kependudukan dan Pencatatan Sipil dapat diketahui beberapa kendala yang menyebabkan Disdukcapil masih belum optimal dari bukti fisik dalam memberikan pelayanan kepada masyarakat disebabkan karena kendala kurang memadainya sarana dan fasilitas yang ada, dana, kompetensi SDM, suasana ruangan yang kurang nyaman karena tidak sesuai jumlah pegawai dengan luasnya ruangan.

\section{Kendala-kendala Pelayanan Di Kantor Disdukcapil Kota Batam dari Segi Responssivenes}

Responsiveness adalah kemampuan petugas pemberi layanan,kejelasan prosedur, dan kecepatan memberikan layanan. Peneliti menemukan kendala di lapangan yaitu:Kemampuan/Skill Teknis Petugas Pemberi Layanan Belum Mumpuni Kemampuan yang dimaksud di sini adalah kapasitas yang dimiliki oleh penyedia jasa dalam memberikan pelayanan kepada pengguna jasa untuk mencapai kepuasan pengguna. Dalam hal ini yang dilihat yaitu bagaimana pengetahuan petugas, kecakapan, keterampilan, tingkat pengalaman kerja, kesungguhan dalam melaksanakan tugas, hasil kerja, dan lain sebagainya. Dalam hal kemampuan petugas dalam memberikan layanan di Kantor Disdukcapil Kota Batam bisa dikatakan masih kurang baik. Berdasarkan observasi yang peneliti lakukan dapat dilihat bahwa kebanyakan dari kemampuan petugas tersebut kurang cepat dalam melayani masyarakat.

\section{Tidak Terdapat Kotak Saran Dalam Kantor Disdukcapil Kota Batam}

Kotak saran sangatlah penting, dalam memberikan masukan dan kritikan yang membangun dalam memperbaiki institusi pemerintahan. Setelah peneliti mengadakan observasi di lapangan, tidak ditemukan kotak saran di kantor Disdukcapil. Pada umumnya sebuah institusi yang profesional seyogyanya meletakkan kotak saran dan kritik sebagai penilaian untuk mengetahui sejauh mana kualitas pelayanan publik yang dilakukan oleh petugas kantor Disdukcapil.

Kotak saran dibikin dalam bentuk kuesioner (angket), dengan mengisi kuesioner tersebut, baik masyarakat maupun kantor telah melakukan akuntabilitas dan transparansi terhadap pelayanan yang terbuka. Kotak saran ini adalah bagian kejujuran yang bisa dijadikan evaluasi terhdap keluhahan pelayanan masyarakat. Kemudian dapat dijadikan tolak ukur untuk perbaiki birokrasi pelayanan publik.

\section{Karakter Birokrat Dari Segi Empati}

Empati dalam penelitian ini adalah kesediaan petugas untuk lebih peduli memberikan perhatian secara pribadi kepada masyarakat. Misalnya petugas harus mencoba menempatkan diri sebagai pihak yang dilayani. Jika masyarakat ada yang merasa tidak puas maka harus dicari jalan keluarnya untuk mencapai kesepakatan dengan menunjukkan rasa tulus. Secara operasional empati ini dijabarkan menjadi beberapa indikator yaitu usaha petugas untuk memberikan layanan yang terbaik, keramahan petugas dalam memberikan layanan, keadilan dalam hal pelayanan, dan kesediaan bekerja lebih lama.

\section{Praktek Pungutuan Liar Di Disdukcapil Kota Batam}

Pemberitaan dari media Batam Pos tanggal 18 Oktober 2016 seakan memberikan peringatan/teguran kepada petugas Disdukcapil Kota Batam bahwa terjadi permasalahan pungutan liar yang dianggap masalah serius.Sebab hal ini akan menurunkan citra (Image) dari Disdukcapil sendiri. Walaupun hanya beberapa oknum yang melakukan, tetap saja mencoreng reputasi Pemerintah Kota Batam. Soal komitmen atau janji yang dijanjikan tidak tepat waktu, lalu kemudian komitmen tidak dipungut bayaran namun pada akhirnya tetap di pungut juga. Oleh karena itu, penting dipikirkan oleh Kepala Dinas Kependudukan dan Pencatatan Sipil agar menerapkan sistem pelayanan yang prima sesuai denan asas pelayanan yang baik.

\section{Sarana dan Pra-sarana Yang Kurang Memadai}

Saran dan Prasarana merupka faktor yang urgen dalam menentuka dalam parameter kualitas pelasanayan publik, namun di Di kantor Disdulcapil ditemukan kurang memadainya sarana dan prasarana 
disebabkan oleh tidak proporsionalnya antara jumlah pegawai dengan luas ruangan di Disdukcapil Kota Batam. Dengan ruangan yang kurang memadai menyebabkan kurang nyamannya pegawai kantor dalam bekerja.Kondisi meja yang rapat ruangan yang sempit mengganggu kelancaran tugas pegawai dalam bekerja. Selain itu, peneliti melihat kantor Disdukcapil Kota Batam memang kurang nyaman, kondisi terebut terlihat pada masih kurang ruang tunggu/ketersediaan tempat duduk untuk mengantri, menyebabkan warga duduk terlalu rapat dengan warga yang lain. Tentu fasilitas ini memberikan pengaruh terhadap pelayanan yang prima di kantor Dinas Kependudukan dan Pencatatan Sipil Kota Batam. Kemudian itu ruang tunggunya tidak dilengkapi dengan alat bacaan, televisi, dan lain sebagainya, sehingga hal itu menimbulkan kebosanan bagi masyarakat yang menunggu nomor antriannya.

Dari pernyataan informan di atas dapat dilihat kendala utama yang menyebabkan tidak memadainya ruang tunggu di Kantor Dinas Kependudukan dan Pencatatan Sipil Kota Batam adalah karena dana untuk membuat ruang tunggu yang memadai tersebut tidak cukup padahal tanahnya cukup luas untuk dibikin ruang tunggu yang lebih layak dan memadai untuk masyarakat Kota Batam. Selain itu berdasarkan observasi yang peneliti lakukan di lapangan dapat dilihat bahwa ruang tunggu itu menghabiskan waktu berjam-jam menunggu giliran tanpa melakukan aktivitas apapun yang akhirnya menimbulkan kebosanan.

Apabila sarana dan pra-sarana tidak mencukupi atau tidak memenuhi standar tentu pelayanan terbaik atau pelayaanan prima yang diinginkan masyarakat itu tidak akan tercapai dan visi misi dari kantor Disdukcapil Kota Batam sendiri tidak akan terwujud yaitu terwujudnya sistem informasi administrasi kependuudkan Kota Batam secara komprehensif, strategis dan dinamis.

\section{Faktor Pendukung Pelayanan Publik Disdukcapil Kota Batam Data Base Online Terintegrasi Secara Nasional (Kemendagri)}

Inovasi data online terintegrasi secara nasional berimplikasi pada tidak memungkinkan lagi data itu ganda. Penerbitan KTP Elektronik (e-KTP) sudah dibuat di Batam tidak boleh lagi dibikin di daerah yang lain. Jadi memudahkan untuk data akurat dalam memverifikasi datanya. Data base online terintergrasi secara nasional ini merupakan faktor pendukung karena membatu petugas memvalidasi data. Hanya saja faktor ini ada data hambatan, misalnya: kadang terdapat masyarakat yang mengajukan permohonan di Disdukcapil ternyata sudah terdaftar di daerah lain atau sudah di rekam sidik jarinya di daerah lain.

Ketika ditemukan data yang tidak valid, dan rekamannya harus direkam ulang atau rekaman sidik jarinya tidak sempurna maka masyarakat wajib direkam ulang, namun kadang ketika disuruh datang kembali masyarakatnya mengeluh dan menyalahkan petugas. Hal ini menjadi faktor alasan dari tabiat/kebiasaan masyarakat yang maunya serba cepat tapi tidak mau mengikikuti aturan prosedur. Bukan ketidak pahaman masyarakat tapi lebih soal "menggampangkan" suatu pelayanan. Tapi di sisi lain ada juga sebagian masyarakat yang tidak mengerti akan prosedur tersebut, oleh karena itu sosialisasi terus dilakukan agar memudahkan masyarakat mendapatkan pelayanan yang baik.

\section{Permohonan Pelayanan Dokumen KTP dan KK Dilakukan Di Kecamatan Tempat Masyarakat Berdomisili}

Dengan adanya pelayanan di kecamatan maka masyarakat tidak perlu lagi datang ke Disdukcapil. Kalau permohonannya cetak KTP tidak ada perubahan, itu langsung selesai di kecamatan. Misalnya KTP hilang atau KTP rusak, dua hal itu bisa ditunggu di kecamatan. Kalau dia ada perubahan yang mengakibatkan dia ada perubahankartu keluarga, misalnya nama anak tetap dilakukan di kecamatan namun diteruskan di Disduk, karena KK nya tetap diterbitkan di Disduk dan tetap ditanda tangani oleh Kepala Dinas hingga nantinya percetakan KTP nya tetap berada di Kecamatan tempat masyarakat berdomisili. 


\section{KESIMPULAN}

Pelayanan publik merupakan salah satu kewajiban yang harus dilaksanakan pemerintah. Salah satu aspek pelayanan publik adalah pelayanan di bidang kependudukan dan pencatatan sipil. Dalam penelitian yang dilakukan Dinas Kependudukan dan Pencatatan Sipil didapatkan sejumlah kesimpulan tentang kendala-kendala yang dihadapi Disdukcapil Kota Batam ditinjau dari segi tangibel, responsibenesss, reability, assurance dan empathy. Dari segi tangibel didapatkan kesimpulan kendala pelayanan Disdukcapil Kota Batam disebabkan kurang dana yang memadai untuk melengkapi fasilitasfasilitas atau sarana dan prasarana. Padahal sarana dan prasarana tidak dapat dipungkiri merupakan hal esensial dalam membantu kelancaran pelayanan publik. Selain itu kendala lain yang menghambat adalah dari faktor leadership (Kepemimpinan) dan kendala sebagian SDM yang masih kurang bermutu dan berkualitas sehingga mempengruhi terhadap proses pelayanan publik di Disdukcapil Kota Batam. Dari segi responsiveness, didapatkan kesimpulan kendala pelayanan di Disdukcapil Kota Batam disebabkan kurangnya pelatihan-pelatihan tentang program pelayanan prima yang diberikan kepada petugas, sehingga kemampuan (sskill) petugas dalam memberikan layanan kepada masyarakat masih kurang baik. Dalam hal kejelasan prosedur di Disdukcapil Kota Batam kendalanya adalah soal sosialisasi yang mesti terus di tingkatkan, karena masih terdapat kesalahpahaman antara petugas dengan masyarakat dalam mengurus dokumen kependudukan, seperti mengurus surat pindah dan lain sebagainya.

Dalam hal tanggap terhadap keluhan masyarakat didapatkan kesimpulan bahwa yang menyebabkan kurang tanggapnya petugas terhadap keluhan masyarakat Kota Batam adalah karena sebagian petugas-petugas yang ada di Disdukcapil Kota Batam belum menjadikan diri mereka sebagai orang yang melayani, sehingga ada bebearapa orang petugas yang apatis terhadap keluhan masyarakat yang lagi mengurus dokumen kependudukan. Dari segi reability, didapatkan kesimpulan kendala yang menghambat pelayanan prima di Kota Batam adalah keandalan petugas dari segi waktu yangcepat, tepat dan sesuai dengan waktu yang dijanjikan belumlah terwujud sepenuhnya. Sebab sebagian petugas masih mengharapkan pungli (pungutan liar) agar kepengurusan di Disdukcapil mempermudah segala urusan. Belum lagi persoalan calo yang memanfaatkan situasi dan kondisi dengan uang jasa yang amat besar untuk mempermudah urusan dokumen kependudukan yang dibutuhkan oleh masyarakat.

Dari segi assurance, didapatkan kesimpulan kendala yang menghambat proses pelayanan prima di Disdukcapil Kota Batam adalah karena Sumber Daya Manusianya yang statis atau tidak berkembang. Masih didapatkan sebagian petugas yang belum kompeten sesuai dengan tupoksinya. Jelas faktor kompetensi ikut mempengaruhi pelayanan yang prima kepada masyarakat.

Dari segi empathy, didapatkan kesimpulan bahwa kendala faktor sikap individu petugas yang kadang tidak bersikap ramah dan sopan kepada masyarakat. Namun juga kesalahan tersebut tidak selalu sepenuhnya ada di pihak petugas Disdukcapil, karena ada juga ada sebagian masyarakat yang kurang mengerti terkait dengan prosedur regulasi dokumen kependudukan, sehingga ini memunculan permasalahan seperti data ganda, kurangnya kelengkapan berkas dan lain sebagainya.

Sedangkan faktor pendukung dari pelayanan Disdukcapil itu sendiri disimpulkan data base sudah terintegrasi secara nasional, permohonan pelayanan KTP dan KK dilakukan di kecamatan tempat masyarakat berdomisili, permohonan akte kelahiran dapat dilakukan di kelurahan, kerja sama/MOU dengan pihak RSUD untuk penertibitan akte kelahiran, dan regulasi pelayanan dokumen kependudukan UU No.24 Tahun 2013 dilanjutkan lagi perda Nomor 1 Tentang Pelaksanaan Administrasi Kependudukan Kota Batam. 


\section{DAFTAR PUSTAKA}

[1]. Dwiyanto, Agus. 2010. Mewujudkan Good Governance Melalui Pelayanan Publik. Yogyakarta: Gadjah Mada University Press

[2]. Hidayat, Dayat. 2010. E-government: Hubungan Teknologi Informasi Dengan Administrasi Publik. Makalah yang disampaikan dalam Konferensi Nasional Adminisstrasi Negara Ke-3 di Universitas Padjajaran.

[3]. Rosidin, Utang. 2015. Otonomi daerah dan Desentralisasi. Bandung: CV.Pustaka Setia Silvia

[4]. Sinambela, Lijan Poltak. 2010. Reformasi Pelayanan Publik Teori, Kebijakan dan Implementasi, Jakarta: PT. Bumi Aksara

[5]. Sedarmayanti, Good Governance. 2012. Good Governance (Kepemerintahan Yang Baik Bagian Pertama Edisi Revisi, Bandung: CV.Mandar Maju

[6]. Sugiono. 2012. Metode Penelitian Kuantitatif dan R\&D. Bandung: Alfabeta

[7]. Yudiatmaja, Wahyu Eko. 2012. Dinamika Administrasi Negara Kontemporer. Yogyakarta: Capiya Publishing

[8]. Undang-Undang Tentang Perubahan Atas Undang-Undang Nomor 23 Tahun 2006 Tentang Administrasi Kependudukan

[9]. PP No.41 Tahun 2007 Tentang Organisasi Perangkat Daerah Permendagri Nomor 57 Perda Kota Batam No.12 Tahun 2007 Tentang Pembentukan Struktur Organisasi dan Tata Kerja Dinass Daerah Kota Batam

[10]. Perda Kota Batam No.8 Tahun 2009 Tentang Penyelenggraan Administrasi Kependudukan di Kota Batam

[11]. Peraturan Walikota Nomor 26 Tahun 2010 Uraian Pemerintahan Daerah

[12]. Jurnal JUAN (Jurnal Ilmu Administrasi Negara), volume 1 No.1 juni 2013, Program Studi Ilmu Administrassi Negara Fakultas Ilmu Sosial Dan Ilmu Politik Universitass Maritim Raja Ali Haji

[13]. Saputra, T. (2016). Kepuasan masyarakat terhadap penyelenggaraan pelayanan publik (studi kasus kantor Kecamatan Tambang Kabupaten Kampar). Jurnal Perspektif Pembiayaan dan Pembangunan Daerah, 4(2), 89-100. 